\title{
FROUDE NUMBER VARIANCE WITH RESPECT TO THE HYDRODYNAMIC RESPONSE OF A NON- STATIC VEHICLE ON A LOW-LYING FLOODED ROADWAY
}

\author{
Syed MuZzamil Hussain Shah ${ }^{*}$, Zahiraniza MustafFa ${ }^{2}$, \\ SHABIR HUSSAIN KHAHRO ${ }^{3}$, KHAMARUZAMAN WAN YUSOF ${ }^{2}$, EBRAHIM HAMID \\ HuSSEIN Al-QADAMI ${ }^{2}$, AMINUdDIn AB GHANI ${ }^{4}$ AND FANG Yenn TEO \\ ${ }^{I}$ Civil Engineering Department, \\ Sir Syed University of Engineering and Technology, Karachi, Pakistan \\ ${ }^{2}$ Department of Civil and Environmental Engineering, \\ Universiti Teknologi PETRONAS, Seri Iskandar, Malaysia \\ ${ }^{3}$ College of Engineering, Prince Sultan University, Riyadh, Saudi Arabia \\ ${ }^{4}$ River Engineering and Urban Drainage Research Centre (REDAC), \\ Universiti Sains Malaysia, Seri Ampangan, Malaysia \\ ${ }^{5}$ Faculty of Science and Engineering, University of Nottingham, Semenyih, Malaysia \\ "Corresponding author:drmuzzamil@ssuet.edu.pk
}

(Received: $7^{\text {th }}$ June 2020; Accepted: $27^{\text {th }}$ September 2020; Published on-line: $4^{\text {th }}$ January 2021)

ABSTRACT: In terms of stability, the response of static cars in floodwaters has been widely investigated. However, the hydrodynamics of a non-static vehicle exposed to such events are less explored. Herein the study ponders the assessment of the hydrodynamic forces experienced by a non-static vehicle attempting to cross a low-lying flooded street. With that regards, a Perodua Viva was modeled (1:10) and tested in the Hydraulics Laboratory under partial submergence and sub-critical flows, fulfilling the similarity laws. Since the Froude number could best analyze the flow conditions, the behavior of the hydrodynamic forces and the Froude number have been the focus of this investigation. From the study of outcomes, an inverse relation of the Froude number with respect to the buoyancy force, along with positive trends relating to drag, frictional, and rolling resistance, were noticed.

ABSTRAK: Dari segi kestabilan, tindak balas kereta statik dalam air banjir telah banyak dikaji. Walau bagaimanapun, hidrodinamik kenderaan tidak statik yang terdedah kepada kejadian seperti itu kurang diterokai. Kajian ini menilai daya hidrodinamik kenderaan tidak statik yang cuba melintas jalan raya yang banjir. Sehubungan itu, sebuah Perodua Viva dimodelkan (1:10) dan diuji dalam Makmal Hidraulik di bawah perendaman separa dan didedahkan kepada aliran sub-kritikal, seperti ketika kejadian. Manakala nombor Froude adalah terbaik dalam menganalisa keadaan aliran air. Oleh itu, tindak balas daya hidrodinamik dan nombor Froude menjadi fokus penyelidikan ini. Dapatan kajian menunjukkan kaitan terbalik nombor Froude pada daya apungan, sedangkan tren positif yang berkaitan dengan daya tarik, geseran dan rintangan guling diperhatikan.

KEYWORDS: hydrodynamic forces; Froude number; non-static vehicle; partial submergence; subcritical flow 


\section{INTRODUCTION}

Communities have been menaced by floods for ages. Flood occurrence not only imposes losses to infrastructure and property but it also claims thousands of lives and leaves millions homeless [1]. During flooding, the transportation system is directly damaged due to its considerable size $[2,3]$. Though flooding events can be predicted well before their occurrence, people, including motorists, perish in floodwaters. This at times ends up in the form of vehicle instability that leads to vehicle-related fatalities [4]. It is therefore necessary to investigate the hydrodynamic response of flooded vehicles to ideally reduce the possible disastrous consequences and encourage researchers to continue examining the causes of vulnerability $[5,6]$.

A vehicle, when exposed to floodwaters, undergoes several instability modes mainly due the impact of several hydrodynamic forces. Such impact on a static vehicle (perpendicular to incoming flow direction) was first studied by [7]. A similar approach was then undertaken on a static car parked parallel to the direction of incoming flow under partial submergence [8]. Both studies concluded and proposed values of friction coefficient for static cars keeping in view the condition of road surface and vehicle tires. Later, a theoretical formula was proposed to assess the incipient velocity required to cause a vehicle to become unstable during a flooding event [9]. Since 1993, no studies were performed on the vehicle hydrodynamics. However, in recent years, the stability criterion of modern vehicles (static) have been studied by various authors. This includes the work of [10-18]. From the available data, both experimental and numerical, it appeared that nearly all investigations (1967-2017) pertaining to vehicle behaviour in floodwater are solely devoted to static (parked) cars.

Herein this paper attempts to inquire the hydrodynamic behaviour of a non-static vehicle for the very first time. The experimental investigation was conducted to observe the instability thresholds of a non-static car at varying hydraulic variables. These data points were later used to theoretically assess the varying hydrodynamic forces by means of a simple numerical framework. Lastly, the relationship of hydrodynamic forces with respect to varying Froude numbers has been discussed.

\section{LABORATORY EXPERIMENTAL SETUP}

Academic research in the field of vehicle chassis dynamics are usually very costly and pertain to safety issues concerning prototype testing. Such studies are limited to scaled models [19]. In the current study, experimental investigations were carried out on a nonstatic model vehicle (1:10, Perodua Viva) that ensured all laws of similitude. The description of the vehicle both prototype and model including dimensions and weight are shown in Table 1.

Table 1: Vehicle specifications

\begin{tabular}{cccccc}
\hline Vehicle & Scale & $\begin{array}{c}\text { Length } \\
{[\mathbf{m m}]}\end{array}$ & $\begin{array}{c}\text { Width } \\
{[\mathbf{m m}]}\end{array}$ & $\begin{array}{c}\text { Height } \\
{[\mathbf{m m}]}\end{array}$ & $\begin{array}{c}\text { Kerb } \\
\text { Weight (g) }\end{array}$ \\
\hline Perodua & Prototype & 3575 & 1475 & 1530 & 800000 \\
Viva & Model $(1: 10)$ & 357.5 & 147.5 & 153.0 & 880 \\
\hline
\end{tabular}

Experimental runs with the non-static model were performed at the Hydraulics Laboratory, Universiti Teknologi PETRONAS (UTP), Malaysia. Herein a maximum grade of $5 \%\left(2.86^{\circ}\right)$ was considered to analyze the behavior of a non-static vehicle in floodwaters on a low-lying roadway condition [20] with an area of $4 \times 1.5 \mathrm{~m}^{2}$. The variables measured 
during the experimental runs involved water depth (y) through point gauge, flow velocity (v) by means of velocity meter, and the time taken by the non-static vehicle to cross the flooded roadway. A laser beam was also used to detect vehicle movement in floodwaters. The velocity and water depth measurements were observed at one vehicle length upstream of the flooded vehicle [11] from a moveable hanging bridge. The details of the study area are shown in Fig. 1.

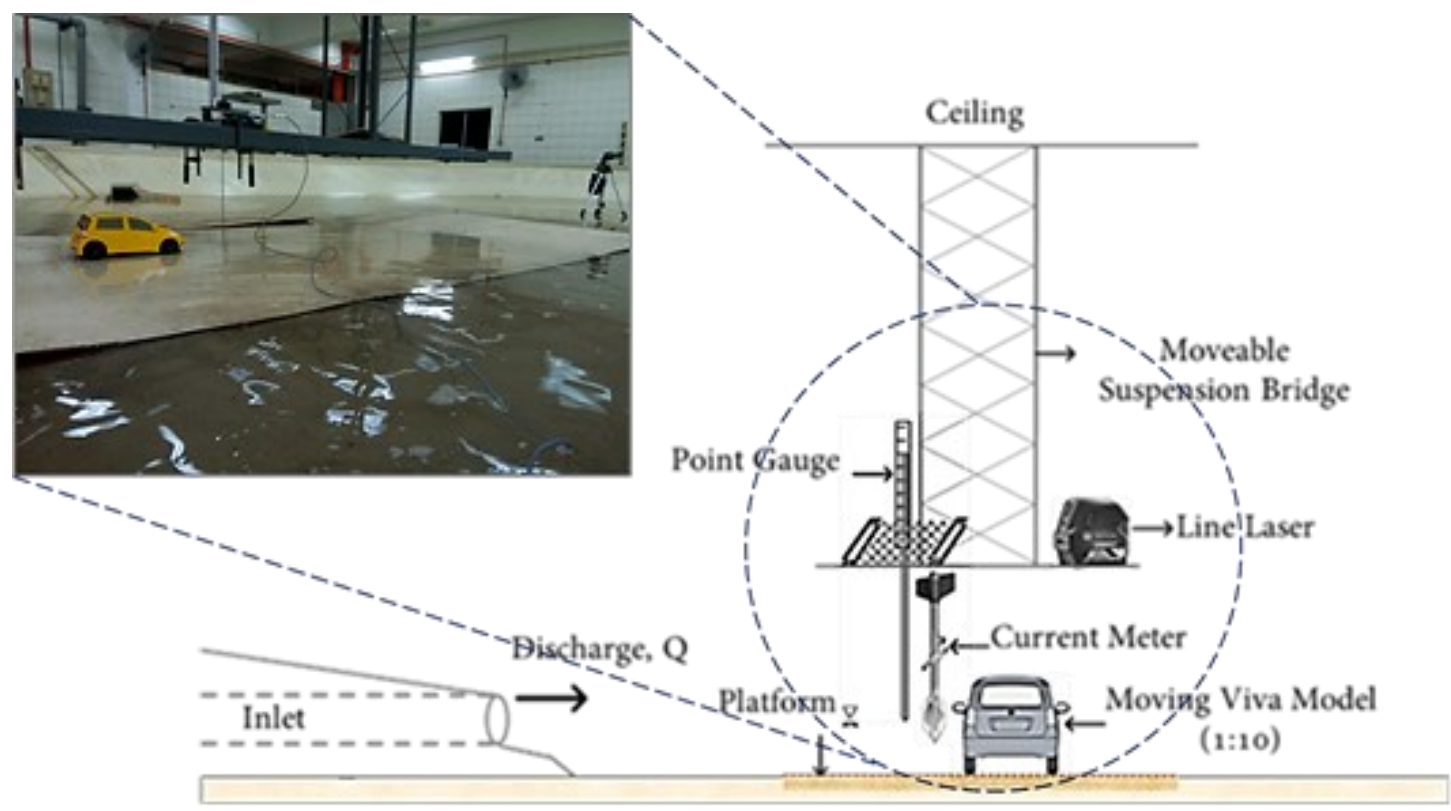

Fig. 1: Description of experimental area [21].

\section{FLOATING DEPTH AND LIMITING THRESHOLDS}

This section highlights the assessment of thresholds and floating conditions of a nonstatic car attempting to cross a low-lying flooded street. In this regard, the response of the car towards varying hydraulic variables has been presented. Since the study scope was limited to partial submergence, the water depths tested were between $0.041 \mathrm{~m}$ to $0.098 \mathrm{~m}$, whereas to ensure sub-critical flow conditions, the observed range for flow velocities were between $0.17 \mathrm{~m} / \mathrm{s}$ to $0.53 \mathrm{~m} / \mathrm{s}$, respectively. The range of Froude and Reynolds numbers attained from the empirical investigations are shown in Table 2.

At depths $\geq 0.055 \mathrm{~m}$, a mode of floating instability was witnessed due to the buoyancy force that took effect at high water depths to acquire sufficient submerged volume to cause floating instability failure. On the other hand, below critical depth (the threshold at or above which floating instability occurred mainly due to the vertical push caused by the hydrodynamic forces i.e., buoyancy and lift forces), a mode of sliding instability was observed at low flow velocities mainly due to slope inclination which reduced the frictional strength between the ground surface and the tires. Herein, the laws of similitude were ensured, thus the buoyancy depth that could lead to the floating instability failure and the limiting velocity $\times$ depth $(\mathrm{v} \cdot \mathrm{y})$ functions required to cause sliding failure for the prototype are highlighted in Fig. 2. 
Table 2: Flow state and Reynolds number

\begin{tabular}{|c|c|c|c|c|}
\hline No. & $\begin{array}{c}\text { Velocity } \\
(\mathrm{m} / \mathrm{s})\end{array}$ & $\begin{array}{c}\text { Depth } \\
\text { (m) }\end{array}$ & $\begin{array}{c}\text { Froude } \\
\text { Number }\end{array}$ & $\begin{array}{l}\text { Reynolds } \\
\text { Number }\end{array}$ \\
\hline 1. & 0.40 & 0.047 & 0.59 & 18800 \\
\hline 2. & 0.36 & 0.051 & 0.51 & 18360 \\
\hline 3. & 0.30 & 0.058 & 0.40 & 17400 \\
\hline 4. & 0.27 & 0.063 & 0.34 & 17010 \\
\hline 5. & 0.28 & 0.064 & 0.35 & 17920 \\
\hline 6. & 0.23 & 0.078 & 0.26 & 17940 \\
\hline 7. & 0.53 & 0.041 & 0.84 & 21730 \\
\hline 8. & 0.31 & 0.055 & 0.42 & 17050 \\
\hline 9. & 0.29 & 0.058 & 0.38 & 16820 \\
\hline 10. & 0.28 & 0.064 & 0.35 & 17920 \\
\hline 11. & 0.26 & 0.068 & 0.32 & 17680 \\
\hline 12. & 0.24 & 0.074 & 0.28 & 17760 \\
\hline 13. & 0.23 & 0.079 & 0.26 & 18170 \\
\hline 14. & 0.41 & 0.045 & 0.62 & 18450 \\
\hline 15. & 0.27 & 0.064 & 0.34 & 17280 \\
\hline 16. & 0.26 & 0.070 & 0.31 & 18200 \\
\hline 17. & 0.23 & 0.078 & 0.26 & 17940 \\
\hline 18. & 0.23 & 0.081 & 0.26 & 18630 \\
\hline 19. & 0.39 & 0.047 & 0.57 & 18330 \\
\hline 20 . & 0.29 & 0.059 & 0.38 & 17110 \\
\hline 21. & 0.28 & 0.065 & 0.35 & 18200 \\
\hline 22. & 0.24 & 0.077 & 0.28 & 18480 \\
\hline 23. & 0.22 & 0.083 & 0.24 & 18260 \\
\hline 24. & 0.20 & 0.089 & 0.21 & 17800 \\
\hline 25. & 0.29 & 0.057 & 0.39 & 16530 \\
\hline 26. & 0.29 & 0.060 & 0.38 & 17400 \\
\hline 27. & 0.26 & 0.071 & 0.31 & 18460 \\
\hline 28. & 0.24 & 0.078 & 0.27 & 18720 \\
\hline 29. & 0.20 & 0.087 & 0.22 & 17400 \\
\hline 30. & 0.32 & 0.055 & 0.44 & 17600 \\
\hline 31. & 0.28 & 0.061 & 0.36 & 17080 \\
\hline 32. & 0.26 & 0.072 & 0.31 & 18720 \\
\hline 33. & 0.24 & 0.079 & 0.27 & 18960 \\
\hline 34. & 0.20 & 0.088 & 0.22 & 17600 \\
\hline 35. & 0.38 & 0.051 & 0.54 & 19380 \\
\hline 36. & 0.29 & 0.061 & 0.38 & 17690 \\
\hline 37. & 0.25 & 0.073 & 0.30 & 18250 \\
\hline 38. & 0.21 & 0.085 & 0.23 & 17850 \\
\hline 39. & 0.20 & 0.089 & 0.21 & 17800 \\
\hline 40. & 0.19 & 0.091 & 0.20 & 17290 \\
\hline 41. & 0.41 & 0.046 & 0.61 & 18860 \\
\hline 42. & 0.30 & 0.058 & 0.40 & 17400 \\
\hline 43. & 0.28 & 0.066 & 0.35 & 18480 \\
\hline 44. & 0.26 & 0.072 & 0.31 & 18720 \\
\hline 45. & 0.21 & 0.085 & 0.23 & 17850 \\
\hline 46. & 0.19 & 0.093 & 0.20 & 17670 \\
\hline 47. & 0.25 & 0.068 & 0.31 & 17000 \\
\hline 48. & 0.24 & 0.077 & 0.28 & 18480 \\
\hline 49. & 0.20 & 0.088 & 0.22 & 17600 \\
\hline 50. & 0.19 & 0.094 & 0.20 & 17860 \\
\hline 51. & 0.17 & 0.098 & 0.17 & 16660 \\
\hline
\end{tabular}




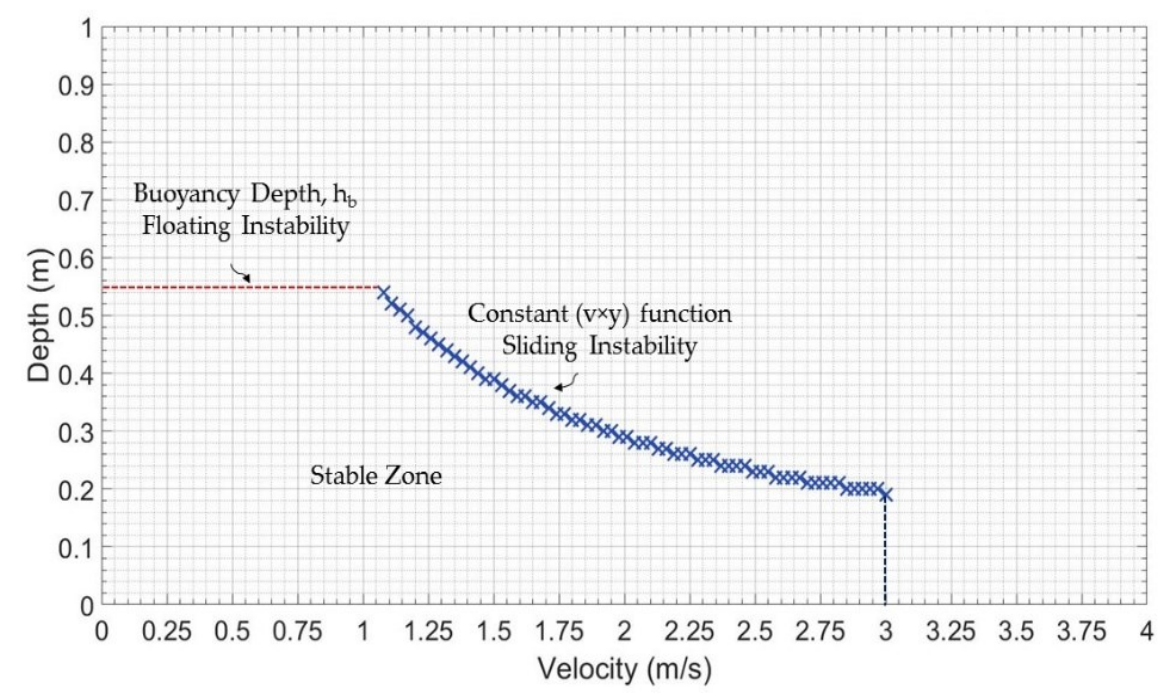

Fig. 2: Limit functions and buoyancy depth for Perodua Viva (1:1) at mild inclinations.

\section{THEORETICAL ASSESSMENT OF HYDRODYNAMIC FORCES}

The hydraulic variables were assessed at the point of maximum inclination. For assessing the buoyancy force, the submerged volume (V) was estimated at the given water depths. Due to the complexity of the slope inclination, the submerged fractions of the vehicle were theoretically determined through AutoCAD, Solidworks, and ANSYS (Fluent).

The description of drag force has been addressed in detail in earlier studies [5, 22] and [23]. Therefore, in the current section the focus was more on the drag influence assisted by the weight component parallel to the inclined plane. At inclinations, the gravitational force has transverse components. Under dry conditions, the parallel component supports the drag force that causes vehicle sliding. However, under wet conditions, when the flow is subcritical, this force component becomes $m g x=\left(W-F_{B}\right)$ sinø. Thus, the resultant drag at slopes can be expressed as $F D=1 / 2 \rho C_{D} A_{D V}{ }^{2}+\left(W-F_{B}\right)$ sinø. Herein, the value of drag coefficient $C_{D}$ remained unchanged and was set to a constant value as the minimum value of Reynolds number was found to be in the order of 16000 [11].

On slopes, the friction force further reduces due to the transverse components of the gravitational force. Therefore, for such conditions, the coefficient of friction was experimentally determined (wet surface) by means of the spring-balance method. The value of the friction coefficient $\left(\mu_{\mathrm{FR}}\right)$ opposite to the direction of incoming flow was noticed to be 0.19 , whereas the value of the rolling coefficient $\left(\mu_{\mathrm{RO}}\right)$ in the direction of vehicle movement was noticed to be 0.048 .

\section{RESULTS AND DISCUSSION}

Free surface flows are governed by gravity forces, whereas Reynolds number effects (viscous drag) are most likely to become more significant at lower a Reynolds number [24]. Therefore, in this section, an attempt has been made to study the relation of varying hydrodynamic forces with respect to the Froude number.

\subsection{Buoyancy Force $\left(F_{B}\right)$ and Froude Number}

At first, the impact of the buoyancy force computed at varying Froude numbers has been discussed as shown in Fig. 3 . 


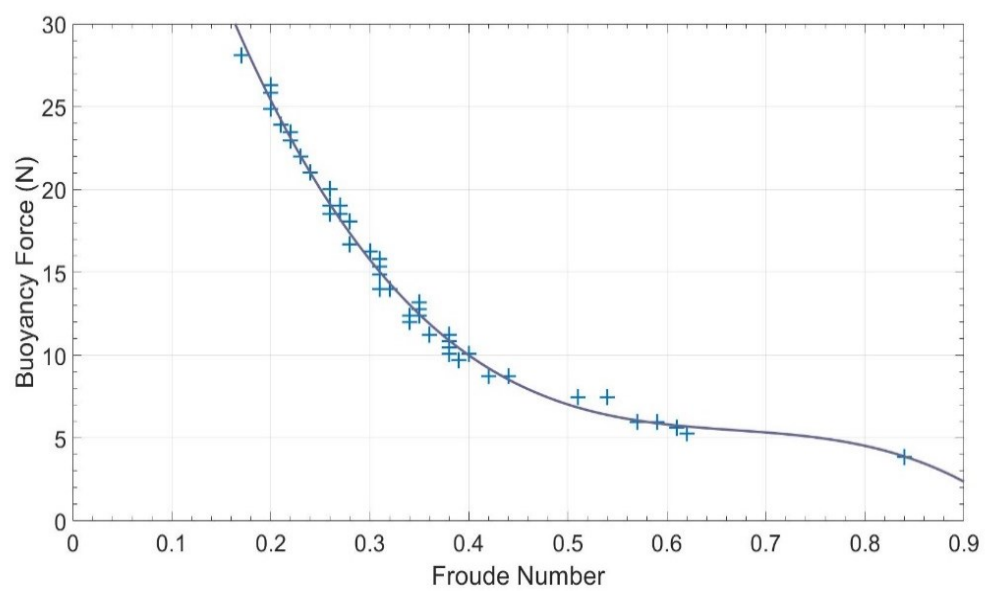

Fig. 3: Buoyancy force computed at varying Froude numbers.

Recall that the buoyancy force relates to the submerged volume that varies with the water depth. Therefore, at each increment in the floodwater level, a decline in the Froude number was seen. For example, when the Froude number reached a low value, i.e., 0.18, the impact of the buoyancy force almost approached $28 \mathrm{~N}$, whereas its impact was insignificant at the highest Froude number, i.e., 0.84. Therefore, from the above graph, it can be figured that there would always be an opposite relation between Froude number and the buoyancy force. Overall, it was noticed that due to subcritical flow conditions, the influence of water depth remained dominant for the majority of the data points.

\subsection{Drag Force $\left(F_{D}\right)$ and Froude Number}

The impact of drag force on non-static vehicles varies based on two conditions, namely (i) the incoming flow direction and (ii) the direction of vehicle movement. For the given circumstances where a vehicle slowly progresses perpendicular to the incoming flow, the drag usually acts at two sides, i.e., vehicle's side end $\left(\mathrm{D}_{1}\right)$ and its frontal area $\left(\mathrm{D}_{2}\right)$. Pertaining to drag influence at $\mathrm{D}_{1}$, it was noticed that its impact did not necessarily increase with respect to the increment in water depth which mainly occurred due to variation in the hydraulic variables. However, at $\mathrm{D}_{2}$, the drag force relied solely on the water depth due to constant velocity of the flow. That is why the impact of drag in this particular direction increased with an increment in the water level.

Under this section, the behavior of drag with respect to the Froude number has been discussed. It is important to highlight that in order to cause floating failure, the influence of buoyancy and lift forces is usually considered. Herein, the investigation noticed that under the conditions where Froude number $<1$, the impact of the lift force was disregarded [17, 25]. Furthermore, for determining the sliding instability, the horizontal pushing force, which comprises drag, friction, and driving force, was taken into account. The impact of the horizontal pushing force is always dominant below critical water depth. However, under this section, the impact of the drag force $\left(D_{1}\right)$ for all data points has been highlighted, as shown in Fig. 4. Later, only those data points that were below critical water depth have been discussed, as shown in Fig. 5.

From the graph, it can be inferred that with an increase in the Froude number, the magnitude of the drag force slightly increased, mainly due to the flow velocity which was more dominant below the buoyancy depth. However, upon comparing the drag influence at vehicle's side with respect to Froude number, it can be seen that when the Froude number reached 0.83 , the drag force was noticed to be $0.75 \mathrm{~N}$, whereas at the lowest Froude number, 
i.e., 0.51 , the drag impact was almost $0.58 \mathrm{~N}$. Thus, a positive relation between the two was witnessed. Similarly, the impact of drag force $\left(\mathrm{D}_{2}\right)$ for all data points has been highlighted, as shown in Figure 6. Later, only those data points that were below critical water depth have been discussed, as shown in Fig. 7.

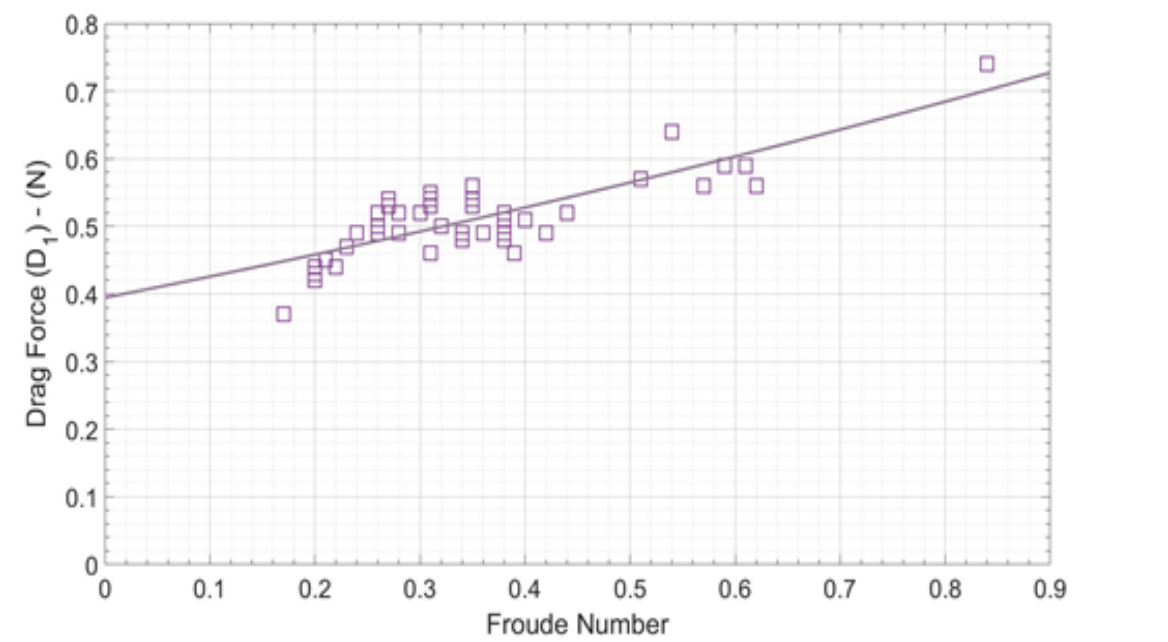

Fig. 4: Drag force $\left(\mathrm{D}_{1}\right)$ computation at varying Froude numbers (all data points).

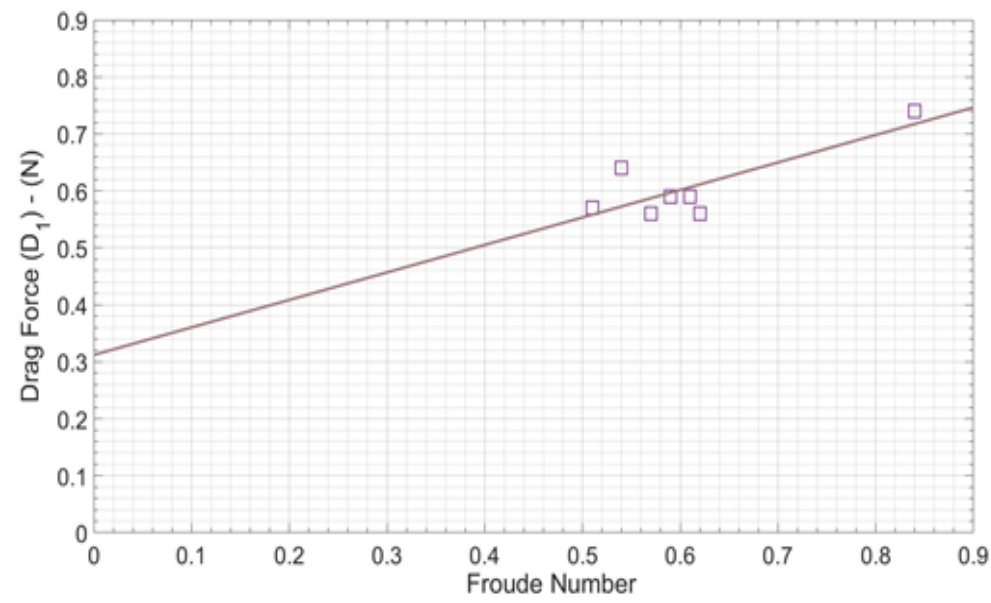

Fig. 5: Drag force $\left(D_{1}\right)$ computation at varying Froude numbers (data points below critical water depth).

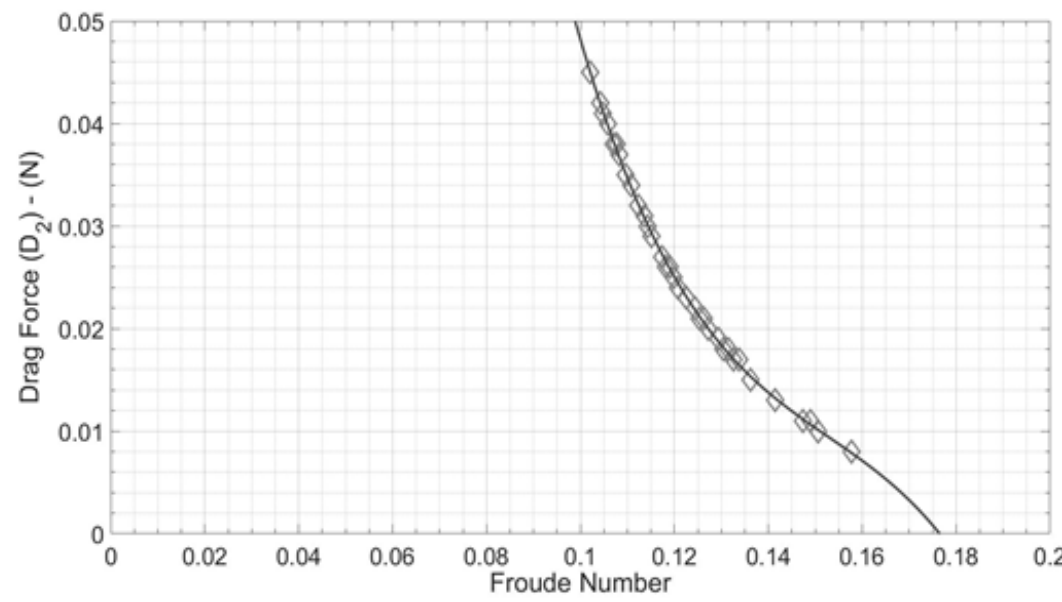

Fig. 6: Drag force $\left(D_{2}\right)$ computed at varying Froude numbers (all data points). 


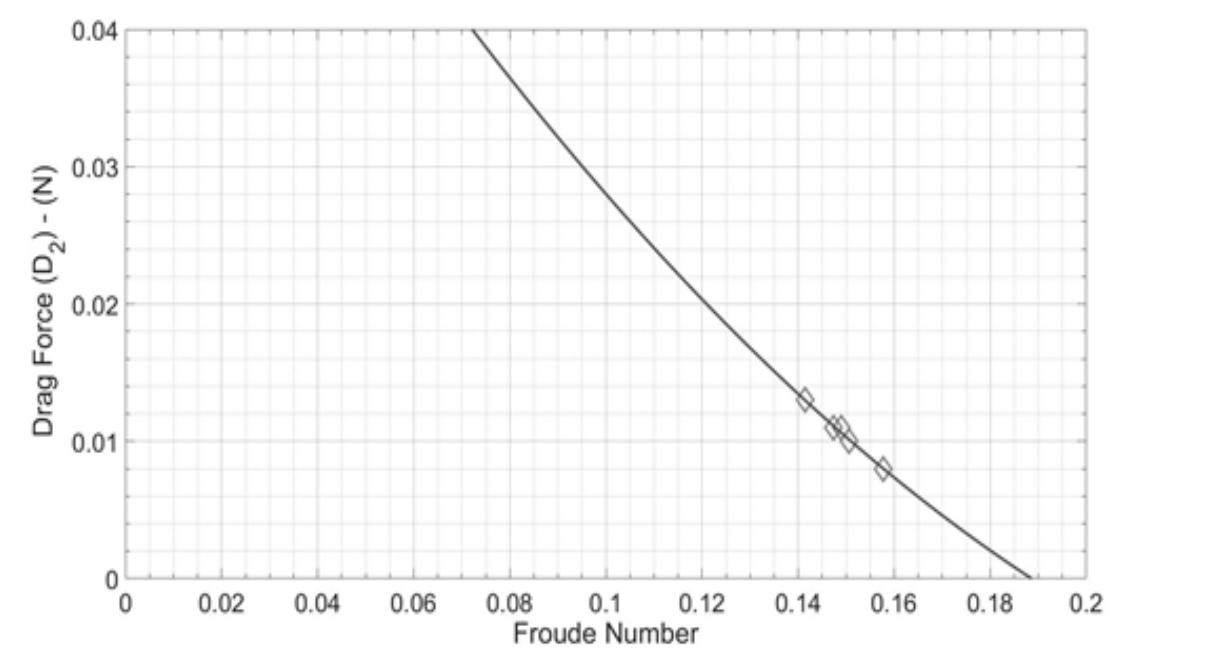

Fig. 7. Drag force $\left(\mathrm{D}_{2}\right)$ computed at varying Froude numbers (data points below critical water depth).

From the above figures, it can be observed that the magnitude of the drag force at the vehicle's front end decreased as the Froude number increased. It should be taken into account that in this particular direction, the flow velocity was found to be very low and constant throughout. Further, the impact of the drag force mainly relied on the floodwater depth. The reason for the nominal impact at the vehicle's front area could be due to two possible reasons, namely (i) low and constant flow velocity in the opposite direction of vehicle movement and (ii) smaller area available to the drag force to take effect. For instance, when the Froude reached 0.158 , the drag impact was found to be $0.008 \mathrm{~N}$, whereas at the highest Froude number, i.e., 0.142, the drag impact was found to be $0.012 \mathrm{~N}$. Thus, a negative relation between the two was witnessed.

\subsection{Friction Force ( $F_{R}$ and $\left.F_{R O}\right)$ and Froude Number}

Recall that for the estimation of the friction force, the net vehicle weight, which can be estimated by deducting the vertical pushing force, i.e., buoyancy and lift forces, from the vehicle weight in dry conditions, is required. However, due to the subcritical state of the flow, the net vehicle weight was assessed by deducting the buoyancy force only. As highlighted earlier, the impact of friction force is dominant below critical water depth. Thus, for the sake of comparison, the variation of frictional resistance $\left(F_{R}\right)$ in the direction of incoming flow with respect to the Froude number on the low-lying roadway for all data points and below critical water depth is highlighted in Fig. 8 and Fig. 9, respectively. Similarly, the variation of rolling resistance $\left(\mathrm{F}_{\mathrm{RO}}\right)$ due to the tires' movement with respect to the Froude number on the low-lying roadway for all data points and below critical water depth, is highlighted in Fig. 10 and Fig. 11, respectively.

The friction force, $F_{R}$ is the resistive force between the vehicle tires and the ground. To cause floating instability, the buoyancy impact was found to be more dominant when it reached the critical depth. Below critical depth, it was noticed to be slightly less effective but since an increment in the water depth reduces the vehicle weight, the frictional stability between the tires and the ground was reduced, as shown in Fig. 12(a). Therefore, it can be said that at low Froude numbers, the frictional stability is reduced and vice versa. Moreover, the weight components at an inclination affect the vehicle weight and so does the instability modes, as shown in Fig. 12(b). 


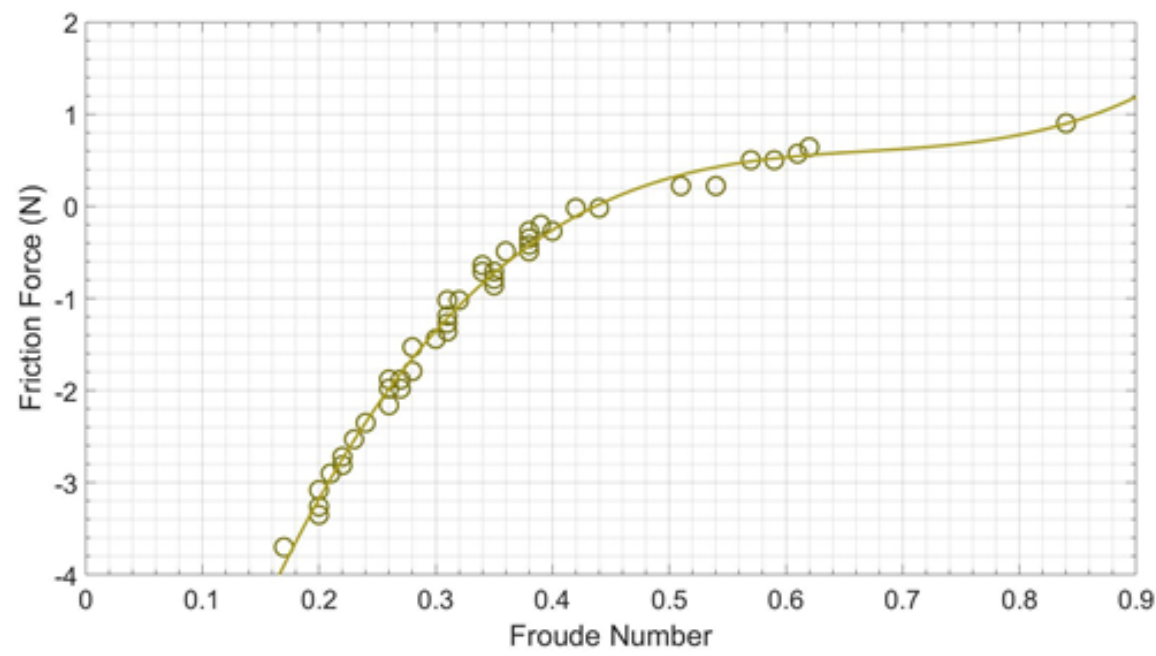

Fig. 8: Friction force $\left(F_{R}\right)$ computation at varying Froude numbers (all data points).

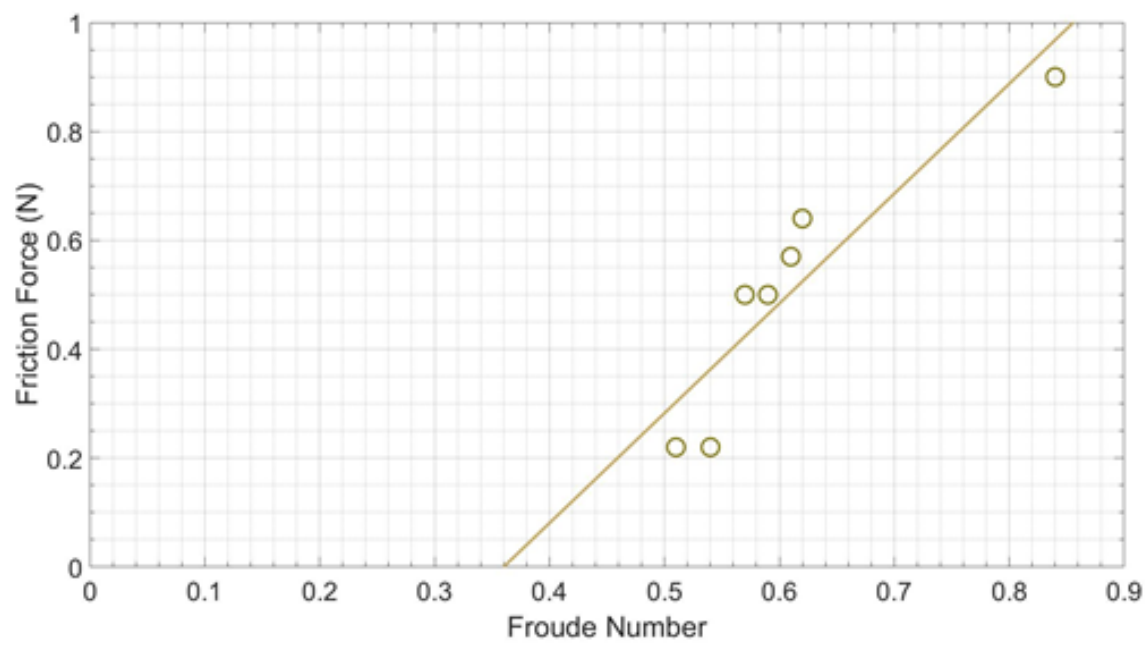

Fig. 9: Friction force $\left(F_{R}\right)$ computation at varying Froude numbers (data points below critical water depth).

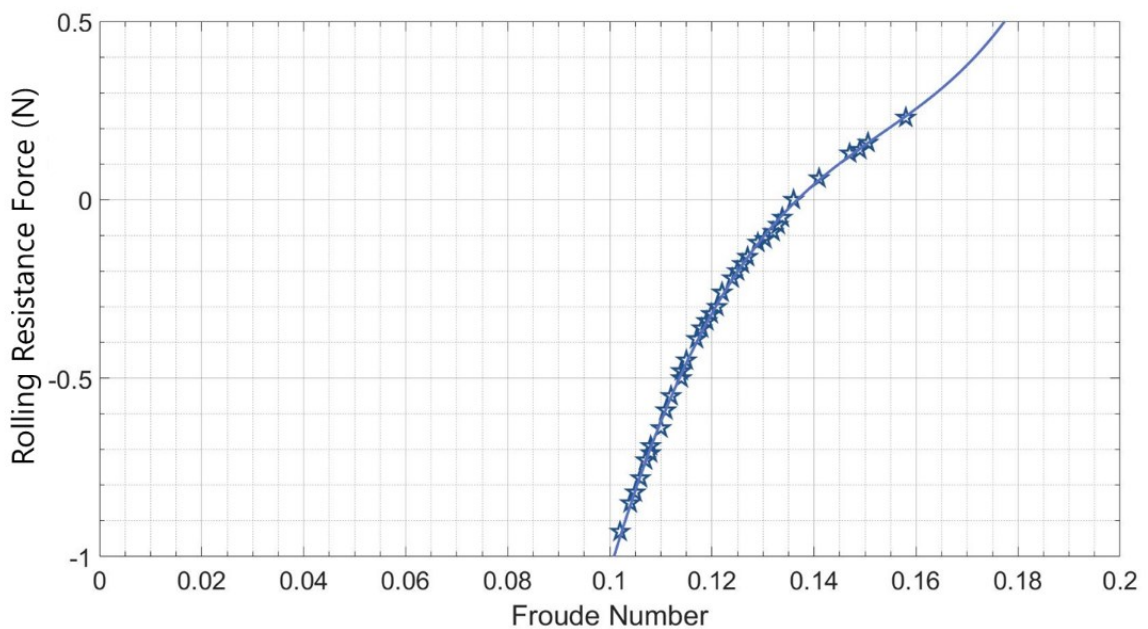

Fig. 10: Friction force $\left(F_{R O}\right)$ computation at varying Froude numbers (all data points). 


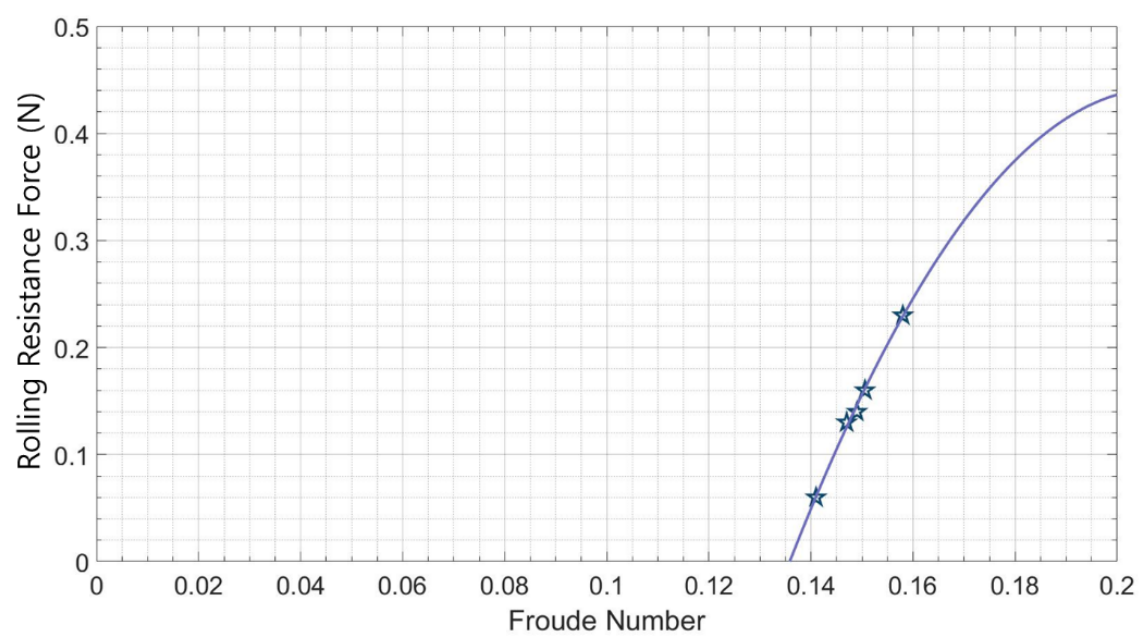

Fig. 11: Friction force $\left(\mathrm{F}_{\mathrm{RO}}\right)$ computation at varying Froude numbers (data points below critical water depth).

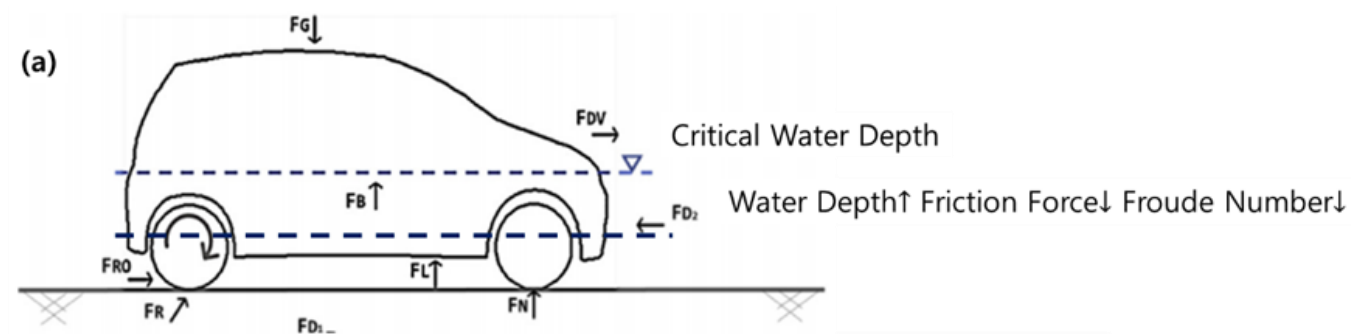

(b)

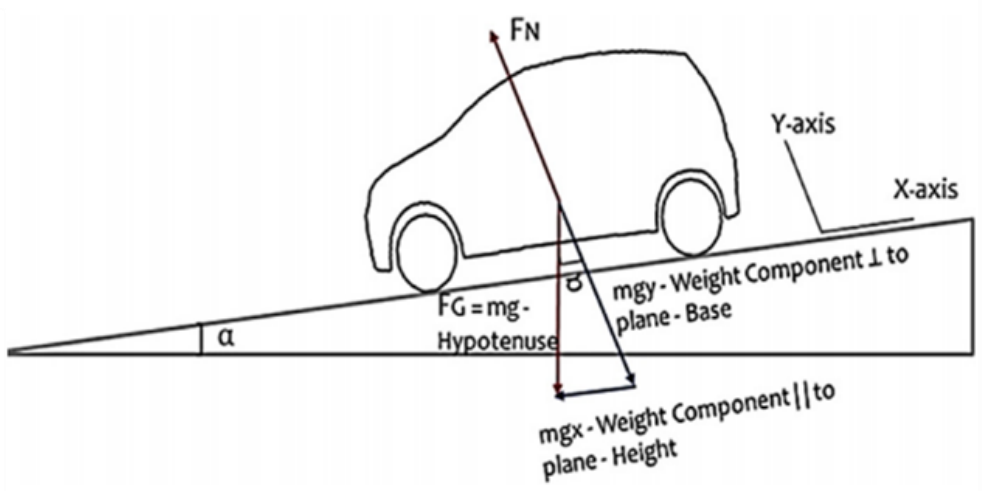

Fig. 12: (a) Hydrodynamic forces on a non-stationary vehicle in floodwaters highlighting the relation between buoyancy and friction forces and (b) Weight components distribution when the ground slope is at an angle [21].

The tires grip with the ground decreases as the water level increases around the vehicle. This further reduces the Froude number. Thus, a positive relation between the two was noticed. At high Froude number, the impact of buoyancy force was low due to low water depths. Therefore, the contact of the vehicle with the ground was strong which increased the frictional resistance. On the other side, when the value of the Froude number was low, the impact of the buoyancy force was high due to high water depths. Thus, the vehicle weight in water was reduced which loosened the frictional resistance between the tires and the ground surface. Concerning the frictional force $\left(F_{R}\right)$, at the lowest Froude number, i.e., 0.51 , the frictional resistance was found to be minimal, i.e., 0.20 , whereas at the highest Froude number, the frictional resistance was comparatively very large. Similarly, the 
influence of rolling resistance $\left(\mathrm{F}_{\mathrm{RO}}\right)$ due to tires' rotation followed a similar pattern. For example, at the lowest Froude number, i.e., 0.14, the rolling resistance was found to be minimal, whereas it reached a larger value when the Froude number reached 0.16.

\section{CONCLUSIONS}

Among the major findings, it's been noticed that: (i) the influence of buoyancy force solely depends on the submerged volume, which varies with the water level whereas the Froude number is inversely proportional to it. Thus, an inverse relation between the two was noticed, (ii) the flow velocity was more dominant below the critical depth, thus the intensity of drag force $\left(\right.$ at $\left.\mathrm{D}_{1}\right)$ slightly increased as the Froude number was increased. On the other hand, at $\mathrm{D}_{2}$, an inverse variation between the two was found and lastly, (iii) the vehicle weight reduced at higher water depths, which decreased the frictional stability of the car with the ground. Thus, it can be said that the frictional stability of a vehicle is reduced at low Froude numbers.

\section{REFERENCES}

[1] Diakakis M, Deligiannakis G. (2017) Flood Fatalities in Greece: 1970-2010. Journal of Flood Risk Management, 10(1): 115-123.

[2] Starita S, Scaparra MP, O'Hanley JR. (2017) A Dynamic Model for Road Protection Against Flooding. Journal of the Operational Research Society, 68(1): 74-88.

[3] Ahmed MA, Haynes K, Taylor M. (2020) Vehicle-related Flood Fatalities in Australia, 2001-2017. Journal of Flood Risk Management, 13:e12616.

[4] Hamilton K, Peden AE, Keech JJ, Hagger MS. (2018) Driving through Floodwater: Exploring Driver Decisions through the Lived Experience. International Journal of Disaster Risk Reduction, 34: 346-355.

[5] Shah SMH, Mustaffa Z, Martinez-Gomariz E, Kim DK, Yusof KW. (2019) Criterion of Vehicle Instability in Floodwaters: Past, Present and Future. International Journal of River Basin Management, 0(0): 1-23.

[6] Teo FY, Falconer RA, Lin B, Xia J. (2012) Investigations of Hazard Risks Relating to Vehicles Moving In Flood. Journal of Water Resources Planning and Management, 1(1): 5266.

[7] Bonham AJ, Hattersley RT. (1967) Low Level Causeways. Water Research Laboratory, Report no. 100. University of New South Wales, Australia.

[8] Gordon A, Stone P. (1973) Car Stability on Road Floodways. Car stability on Road Floodways. National Capital Development Commission, Report no. 73/12. Water Research Laboratory, University of New South Wales, Australia.

[9] Keller RJ, Mitsch B. (1993) Safety Aspects of the Design of Roadways as Floodways. Urban Water Research Association of Australia.

[10] Teo FY. (2010) Study of the Hydrodynamic Processes of Rivers and Floodplains with Obstructions. Thesis (PhD). Available from: https://orca.cf.ac.uk/54161/1/U517543.pdf.

[11] Xia J, Teo FY, Lin B, Falconer RA. (2010) Formula of Incipient Velocity for Flooded Vehicles. Natural Hazards, 58(1): 1-14.

[12] Shu C, Xia J, Falconer RA, Lin B. (2011) Incipient Velocity for Partially Submerged Vehicles in Floodwaters. Journal of Hydraulic Research, 49(6): 709-717.

[13] Oshikawa H, Oshima T, Komatsu T. (2011) Study on the Risk for Vehicular Traffic in a Flood Situation. Advances in River Engineering, 17: 461-466.

[14] Toda K, Ishigaki T, Ozaki T. (2013) Experimental Study on Floating Cars in Flood Water. International Conference on Flood Resilience: Experiences in Asia and Europe.

[15] Xia J, Falconer RA, Xia X, Wang Y. (2013) Criterion of Vehicle Stability in Floodwaters based on Theoretical and Experimental Studies. Natural hazards, 70(2): 1619-1630.

[16] Xia J, Falconer RA, Wang Y, Xia X. (2014) New Criterion for the Stability of a Human Body in Floodwaters. Journal of Hydraulic Research, 52(1): 93-104. 
[17] Martínez-Gomariz E, Gómez M, Russo B, Djordjević S. (2017) A New Experiments-based Methodology to Define the Stability Threshold for any Vehicle Exposed to Flooding. Urban Water Journal, 14(9): 930-939.

[18] Teo FY, Xia J, Falconer RA, Lin B. (2012) Experimental Studies on the Interaction between Vehicles and Floodplain Flows. International Journal of River Basin Management, 10(2): 149-160.

[19] McMahon TA, Bonner JT. (1983) On Size and Life. Scientific American Library.

[20] Romney M (2006). Horizontal and Veritcal Alignment. Massachusetts Highway Department Design Guide Project Development \& Design Guide.

[21] Shah SMH, Mustaffa Z, Martinez-Gomariz E, Yusof KW, Al-Qadami EHH. (2019) Hazard Risks Pertaining to Partially Submerged Non-Stationary Vehicle on Low-Lying Roadways under Subcritical Flows. Results in Engineering, 3 (2019) 100032: 1-7.

[22] Shah SMH, Mustaffa Z, Martinez-Gomariz E, Yusof KW. (2020) Hydrodynamic Effect on Non-Stationary Vehicles at Varying Froude Numbers under Subcritical Flows on Flat Roadways. Journal of Flood Risk Management, 13: e12657.

[23] Shah SMH, Mustaffa Z, Martinez-Gomariz E, Yusof KW, Al-Qadami EHH (2019). A Review of Safety Guidelines for Vehicles in Floodwaters. International Journal of River Basin Management, 0(0): 1-17.

[24] Liu HK, Albertson ML. (1959) Significance and Applications of Froude and Reynolds Numbers as Criteria for Similitude. Report no. CR59HKL20, Colorado State Univesrity, Fort Collins, Colorado.

[25] Shah SMH, Mustaffa Z, Yusof KW, Nor MFM. (2018) Influence of Forces on Vehicle's Instability in Floodwaters. Ain Shams Engineering Journal, 9(4): 3245-3258. 